\title{
The food purchases of elderly women living alone: a statistical inconsistency and its investigation
}

\author{
BY B. S. PLATT \\ Human Nutrition Research Unit, Nutrition Building, National Institute \\ for Medical Research, Mill Hill, London, N.W. 7 \\ P. G. GRAY AND ELIZABETH PARR \\ Central Office of Information, London, S.E. I \\ A. H. J. BAINES, S. CLAYTON, ELIZABETH ANNE HOBSON \\ AND DOROTHY F. HOLLINGSWORTH \\ Ministry of Agriculture, Fisheries and Food, London, S.W. I \\ AND W. T. C. BERRY AND ELIZABETH WASHINGTON \\ Ministry of Health, London, S.E. I \\ (Received I February 1964-Accepted 30 April 1964)
}

Budgetary surveys of the quantities of food obtained for consumption by whole households cannot by their very nature give direct information about the diets of individuals. This may not matter to economists; to nutritionists it is a most serious limitation. There is only one small but important group of households, those consisting of one person, for whom it is prima facie possible to use budgetary records to assess actual food consumption.

Some early National Food Survey records indicated that such assessments were valid. The winter of $1947-8$ was one of privation, judged by current British standards. Bread and potatoes, which had been freely available throughout the war, were both rationed, and during the previous year the people as a whole had lost weight (Kemsley, 1953) and complained publicly about the food supply (Harries \& Hollingsworth, 1953). The continuous survey of the diets of urban working-class households begun in 1940 was therefore suspended for 6 months (October 1947-March 1948) to allow the field workers to concentrate on those groups most likely to be affected by the shortages, especially heavy manual workers' households and old-age pensioners living alone. The sample in each group was augmented by a small initial sample of households providing fresh personal contacts for survey in the neighbourhood. The defects of the method are obvious (Ministry of Agriculture, Fisheries and Food: National Food Survey Committee, 1956, Appendix D), but a rapid survey of very restricted groups could hardly have been made otherwise. The initial sample of pensioners was based on registrations for additional tea for those over 70 years of age, but some of the added pensioners were in their sixties. The resulting sample contained 508 women aged over 6o years: the energy values of their food consumption, estimated from their own 
records of food entering the household and adjusted for changes in larder stocks (but not for wastage), were:

\begin{tabular}{lrrrrr}
\multicolumn{1}{c}{ Age... } & $60-69$ & $70-79$ & $80-89$ & $90-99$ & All \\
No. of persons & 108 & 301 & 95 & 4 & 508 \\
Mean energy value (kcal/day) & 2056 & 1986 & 1866 & 1619 & 1964
\end{tabular}

These results seemed physiologically reasonable, and they are in line with those reported by Durnin \& Blake (I 962 ) for twenty-three women who provided records of their food purchases and whose larder stocks were measured and used in precisely the same way. In 1954, another such study was made of the diets of elderly women living alone and who participated in the National Food. Survey, the only material difference in technique being that changes in household larder stocks were no longer measured in the Survey after June I95I. This change appears to have caused no discontinuity in the records of the total energy value of food obtained for consumption, except in the special group of households now under discussion; and this exception went unnoticed at the time. It came to light when Baines \& Hollingsworth (1955) examined the records of all the 722 women over 55 years of age who lived alone and took part in the Survey between April I953 and March 1954. The energy value of their food was found to range from $2900 \mathrm{kcal} / \mathrm{head}$ daily at $55-64$ to $2400 \mathrm{kcal}$ at 80 and over, the decrease with age being on average between 8 and $9 \%$ of the value for the $60-64$ age-group for each decade after 60 . For each age-group the energy value of food obtained for consumption was roughly $1000 \mathrm{kcal} / \mathrm{head}$ daily greater than the requirement recommended by FAO (1957). Data for single elderly women in each income group were examined at this time and the effect was seen in all, particularly in the highest (Baines and Hollingsworth, unpublished records).

These results were received with surprise amounting to incredulity; it was clearly necessary to find an explanation for them, and this led to a series of investigations described below.

\section{EXPERIMENTAL AND RESULTS}

\section{The investigations}

\section{Data from National Food Survey 1957 and $195^{8}$}

The 1957 National Food Survey sample included 776 pensioner households (i.e. households mainly dependent on contributory or non-contributory state retirement or old-age pensions), and of these 391 consisted of one woman living alone. They recorded about $2660 \mathrm{kcal} / \mathrm{head}$ daily, compared with an estimated requirement of under $2000 \mathrm{kcal}$. This observation confirmed that a large discrepancy between purchases and needs of such persons extended to those in the lowest income groups.

A more detailed analysis by age-groups of the diet of female pensioners living alone in $195^{8}$ gave the results shown in Table $\mathrm{I}$, and established that the $1953^{-4}$ results were not an isolated occurrence.

2. Survey of intake and energy expenditure, Paisley, 1958

An individual dietary survey was made in 1958 on seventeen women between 60 and 69 living alone in Paisley (Durnin, Blake, Brockway $\&$ Drury, 1961). Their mean 
intake and expenditure of energy over 7 days were in good agreement at about rgoo $\mathrm{kcal} /$ head daily. Their recorded food wastage was small, $65 \mathrm{kcal} /$ head daily (Durnin \& Blake, 1962), as is likely when attention is directed to wastage. They also kept budgetary records, and larder stocks were recorded by the interviewer at the beginning and end of the week, as in the National Food Survey for $194^{2-5} \mathrm{r}$. Six other women provided records of larder stocks and purchases only. These budgetary results, expressed in terms of energy value, were almost identical with those of the individual surveys, and were close to the 1947-8 National Food Survey results quoted above. In short, the study supported the view that the intakes recorded for this group of the population by the National Food Survey since $195 \mathrm{I}$ were too high, but did not indicate why.

Table $\mathrm{x}$. Expenditure on food, and energy value and nutrient content of food obtained for consumption by female pensioners living alone, 1958

$\begin{array}{lrrrrr}\text { Age (years)... } & 60-64 & 65-69 & 70-74 & 75-79 & 80 \text { or more } \\ \text { No. of persons } & 52 & 72 & 85 & 68 & 58 \\ \text { Expenditure on food/week } & 345.0 d . & 305.5 d . & 29 s .4 d . & 26 s .3 d . & 245.5 d . \\ \text { Energy vaiue (kcal/day) } & 2916 & 2742 & 2562 & 2480 & 2292 \\ \text { Protein (g/day) } & 82 & 75 & 74 & 71 & 64 \\ \text { Fat (g/day) } & 127 & 117 & 111 & 110 & 94 \\ \text { Carbohydrate (g/day) } & 36 \mathrm{r} & 348 & 317 & 302 & 298 \\ \text { Iron (mg/day) } & 14.8 & 13.7 & 13.4 & 12.1 & 10.7\end{array}$

\section{First Greater London Inquiry}

Possible reasons for the difference between the Paisley results and those of the postI95 I National Food Survey were that the small group in Paisley was unrepresentative, or that food recorded differed from that eaten. To test these possibilities an individual dietary survey was done in January 1959 on eight women aged 60-69 who lived alone in Greater London and who had participated in the National Food Survey between July 1957 and June 1958 .

Procedure. Twenty-two women were eligible for inclusion. One had died, and two were in employment which made it impossible to reach them. Each of the others was first asked by a Survey field worker to take part in a further individual dietary survey, to be done by a Ministry of Health dietician. Seven refused to co-operate, mainly because they had found the first survey too complicated, and two were no longer living alone. The remaining eight completed the individual dietary survey, and said that they found it easier to understand and less troublesome than the previous inquiry.

As in Paisley, the method was that of Garry, Passmore, Warnock \& Durnin (1955) and Durnin, Blake \& Brockway (1957). Amounts of sugar for tea (but not for cooking), jam, marmalade and butter were weighed and left in receptacles for use during the week, the receptacles being replenished when necessary by the dietician. At the end of the week, the quantities remaining were weighed. For milk, an amount sufficient for a day was put into a jug, and the dietician weighed the quantity remaining at her daily visit. She inquired about sweets and snacks, food given to visitors, meals eaten outside the home, how food was cooked, how dishes were made up, and whether any food was uneaten after it had been weighed. The names and composition of proprietary 
foods as stated on the labels were noted. For sauces and gravies, which could not be weighed, the informant was asked to estimate the size of the portion. Wastage was not mentioned until 4 days' food intake had been recorded, but during the last 3 days the informants were asked to record the amount of edible waste on the plate, and to keep food discarded during preparation until the dietician's next visit; its weight was then estimated. At the same time informants were questioned about food given to domestic pets and how uneaten bread had been disposed of (e.g. crusts thrown away or made into puddings or given to birds).

Table 2. Elderly women, aged 60-69, First Greater London Inquiry: mean daily energy value and content of protein, fat and carbohydrate in each individual's diet

\begin{tabular}{|c|c|c|c|c|c|c|}
\hline $\begin{array}{c}\text { Subject } \\
\text { no. }\end{array}$ & $\begin{array}{l}\text { First } \\
4 \text { days }\end{array}$ & $\begin{array}{c}\text { Last } \\
3 \text { days } \\
\text { Energy value }(\mathrm{kcal})\end{array}$ & Mean & $\begin{array}{l}\text { First } \\
4 \text { days }\end{array}$ & $\begin{array}{c}\text { Last } \\
3 \text { days } \\
\text { Protein }(\mathrm{g})\end{array}$ & Mean \\
\hline I & 2200 & 1617 & 1949 & 103 & 53 & 82 \\
\hline 2 & 2197 & 2099 & 2155 & 76 & 65 & 71 \\
\hline 3 & 1924 & 2089 & 1995 & 79 & 71 & 75 \\
\hline 4 & 2796 & 2178 & $253 \mathrm{I}$ & 84 & 77 & $8 x$ \\
\hline 5 & 1786 & 1547 & 1684 & 74 & 54 & 65 \\
\hline 6 & 1314 & 2050 & 1629 & 38 & 65 & 50 \\
\hline 7 & 718 & $5^{84}$ & 660 & 32 & 30 & 31 \\
\hline 8 & 2277 & 2314 & 2293 & 75 & 69 & 72 \\
\hline Mean & 1902 & 1810 & 1862 & 70 & 60 & 66 \\
\hline $\begin{array}{c}\text { Subject } \\
\text { no. }\end{array}$ & \multicolumn{3}{|c|}{ Fat $(g)$} & \multicolumn{3}{|c|}{ Carbohydrate (g) } \\
\hline $\mathbf{I}$ & 108 & 84 & 97 & 208 & 164 & 189 \\
\hline 2 & 97 & 106 & 101 & 256 & 221 & $24 \mathrm{I}$ \\
\hline 3 & 104 & 126 & 116 & 162 & 169 & 165 \\
\hline 4 & 146 & 108 & 130 & 282 & 216 & 254 \\
\hline 5 & 75 & 69 & 70 & $2 \times 2$ & 179 & 198 \\
\hline 6 & 43 & 86 & 61 & 194 & 247 & 216 \\
\hline 7 & 27 & 36 & 31 & 85 & 75 & $8 \mathrm{I}$ \\
\hline 8 & 92 & 96 & 94 & 287 & 298 & 292 \\
\hline Mean & 86 & 89 & 87 & 211 & 196 & 204 \\
\hline
\end{tabular}

Results. Table 2 gives results in terms of calories, protein, fat and carbohydrate for these eight women. Neither set of intake values incorporates any allowance for preparation or plate wastage. There was no evidence that the women changed their normal food habits during the survey week; even no. 7 , with a very low intake, appeared to be following her usual pattern of meals. No. 6 was ill for 2 days, and took only milk beverages, so that her daily intake was ${ }^{1} 3_{4} 4 \mathrm{kcal}$ for the first 4 days compared with $2050 \mathrm{kcal}$ in the last 3 . Preparation and plate waste were exceedingly low (Table 3 ). There was some fall in individual intakes between the first 4 days and the last 3 , when information on wastage was being collected; excluding no. 6 , the decrease averaged about $10 \%$, but on these numbers it did not attain statistical significance. Three of the women owned cats, but bought special food, other than milk, for them. One subject had one meal outside the home and recorded it; six 'visitor meals' occurred and food consumed by the visitors was excluded. 
Discussion. Table 3 compares the results of this individual survey with the National Food Survey records for those aged 60-69 in the 1953-4 sample (Baines \& Hollingsworth, 1955), for all women aged 60-69 living alone who provided Survey records in January-March $195^{8}$, and for the eight subjects described here when they took part in the Survey in $1957^{-8}$. The Paisley results (from Durnin et al. 1961) are also shown. All the National Food Survey values are at one level, around $2900 \mathrm{kcal}$, about 1000 kcal higher than the individual dietary results, which at Paisley were supported by conformity to actual energy requirements as indicated by calorimetry. This finding suggested that different survey methods led to differences in buying behaviour by the same group of women.

Table 3. Surveys on elderly women aged 60-69 years: mean daily energy value and content of protein, fat and carbohydrate in diets of National Food Survey samples compared with corresponding ranges for individual dietary surveys

\begin{tabular}{|c|c|c|c|c|c|c|}
\hline & \multicolumn{3}{|c|}{ National Food Survey } & \multicolumn{3}{|c|}{ Individual dietary surveys } \\
\hline & \multirow{2}{*}{$\begin{array}{l}\text { Apr. } \\
1953^{-} \\
\text {Mar. } \\
1954\end{array}$} & \multirow{2}{*}{$\begin{array}{l}\text { Jan.- } \\
\text { Mar. } \\
\text { I958 }\end{array}$} & \multirow{2}{*}{$\begin{array}{l}\text { 1957-8, } \\
\text { Greater } \\
\text { London }\end{array}$} & \multicolumn{2}{|c|}{$\begin{array}{l}\text { First Greater London } \\
\text { Inquiry, I959 }\end{array}$} & \multirow{2}{*}{$\begin{array}{c}\text { Paisley, 1958 } \\
\text { (Durnin et al. } \\
\text { 196I) } \\
\text { Intake }\end{array}$} \\
\hline & & & & Intake & Wastage & \\
\hline Energy value (kcal) & 2867 & 2901 & 2907 & I862 & 36 & 1894 \\
\hline Total protein (g) & 89 & 79 & 91 & $65 \cdot 8$ & $\mathrm{~J} \cdot 3$ & $62 \cdot 4$ \\
\hline Fat $(g)$ & 119 & I3I & 129 & $87 \cdot 4$ & 0.8 & $85 \cdot 7$ \\
\hline Carbohydrate (g) & 380 & 351 & 344 & $204 \cdot 5$ & $5 \cdot 8$ & $232 \cdot 1$ \\
\hline No. & 320 & 50 & 8 & 8 & 8 & 17 \\
\hline \multicolumn{7}{|l|}{ Ranges } \\
\hline Energy value (kcal) & - & - & - & $660-2531$ & $0-114$ & $1107-2283$ \\
\hline Protein $(\mathrm{g})$ & - & - & 一 & $30 \cdot 7-81 \cdot 5$ & $0-4 \cdot 2$ & $29 \cdot 2-85 \cdot 0$ \\
\hline Fat $(\mathrm{g})$ & - & - & - & $31 \cdot 1-130.0$ & $0-2 \cdot 9$ & $50 \cdot 4-105 \cdot 2$ \\
\hline Carbohydrate (g) & - & - & - & $80 \cdot 6-291 \cdot 8$ & $0-22.5$ & $143.0-313.1$ \\
\hline
\end{tabular}

Table 4 indicates where these differences lay. The adjustment of the quantities recorded in the Greater London individual survey to weights 'as purchased' is subject to errors, but these could not obscure the large differences found for the storable foods, fats, sugar, flour and potatoes. National Food Survey results for all women aged 60-69 living alone who provided records in the first quarter of 1958 are given for comparison; allowing for seasonal and geographical differences, they show that the food consumption of the eight women was typical of the group from which they were drawn. When they were recording their meals they 'consumed' less than half as much sugar and potatoes and about half as much fats as when they were simply recording their purchases; and in particular they used almost no flour, margarine or cooking fats. The corresponding differences for milk and bread, which are commonly thought to be wasted, were quite small. Those for fresh fruit and fresh green vegetables should be discounted as being largely seasonal, and they contribute little to the energy value of the diet. The Paisley inquiry also showed much lower consumption of fats, sugar, flour and potatoes than the National Food Survey samples. Fats, sugar and flour are normally used in large amounts where there is much home baking. All the eight London women had their own gas cookers, on which they cooked meat, savoury 
Table 4. Surveys of elderly women, aged 60-69: mean weekly consumption of specified foods (oz/head unless otherwise stated)

\begin{tabular}{|c|c|c|c|}
\hline & & First Grea & ondon Inquiry \\
\hline & $\begin{array}{c}\text { Great } \\
\text { Britain } \\
\text { NFS, } \\
\text { Ist quarter } \\
\text { 1958 }\end{array}$ & $\begin{array}{l}\text { NFS } \\
1957-8\end{array}$ & $\begin{array}{c}\text { Individual } \\
\text { dietary survey, } \\
\text { I } 959, \\
\text { adjusted to } \\
\text { 'as purchased' } \\
\text { weights }\end{array}$ \\
\hline o. in sample... & so & 8 & 8 \\
\hline (pint equivalent) & $\begin{array}{l}5.8 \\
0.2\end{array}$ & $\begin{array}{l}5 \cdot 3 \\
0.1\end{array}$ & $\begin{array}{l}4 \cdot 6 \\
0 \cdot 1\end{array}$ \\
\hline seam (pint oripint equivalent) & $6 \cdot 0$ & $5 \cdot 4$ & $4 \cdot 7$ \\
\hline & $3 \cdot 1$ & $5 \cdot 6$ & $3 \cdot 8$ \\
\hline & $\begin{array}{r}19.1 \\
5.6 \\
10.9\end{array}$ & $\begin{array}{r}29.5 \\
5.4 \\
7.2\end{array}$ & $\begin{array}{r}22 \cdot 5 \\
9 \cdot 3 \\
10 \cdot 1\end{array}$ \\
\hline & $35^{\cdot 6}$ & $42 \cdot 1$ & $41 \cdot 9$ \\
\hline & 10.0 & $19 \cdot 8$ & $12 \cdot 1$ \\
\hline & $\begin{array}{l}4 \cdot 4 \\
8 \cdot 7 \\
2 \cdot 9 \\
5 \cdot 0\end{array}$ & $\begin{array}{l}5.0 \\
6.0 \\
3.0 \\
3.3\end{array}$ & $\begin{array}{l}3.8 \\
6.3 \\
0.1 \\
0.4\end{array}$ \\
\hline & $16 \cdot 6$ & $12 \cdot 3$ & 6.8 \\
\hline & $\begin{array}{r}18 \cdot 9 \\
7 \cdot 0\end{array}$ & $\begin{array}{r}20.0 \\
4.0\end{array}$ & $\begin{array}{l}8.0 \\
3.1\end{array}$ \\
\hline preserves & $25^{\circ} 9$ & $24 \cdot 0$ & I I'I \\
\hline tables & $\begin{array}{l}45 \cdot 4 \\
12 \cdot 3 \\
21 \cdot 3\end{array}$ & $\begin{array}{r}58.0 \\
28.5 \\
9.4\end{array}$ & $\begin{array}{r}26.2 \\
7.3 \\
2.5\end{array}$ \\
\hline & $79 \cdot 0$ & $95^{\circ} 9$ & $36 \cdot 0$ \\
\hline & $\begin{array}{r}19 \cdot 1 \\
6 \cdot 4\end{array}$ & $\begin{array}{r}34 \cdot 8 \\
2 \cdot 0\end{array}$ & $\begin{array}{r}10.4 \\
3.0\end{array}$ \\
\hline & $25 \cdot 5$ & $36 \cdot 8$ & $13 \cdot 4$ \\
\hline & $\begin{array}{l}45 \cdot 8 \\
11 \cdot 5\end{array}$ & $\begin{array}{l}33 \cdot 3 \\
12 \cdot 0\end{array}$ & $\begin{array}{r}37.5 \\
0.6\end{array}$ \\
\hline ite & $\begin{array}{r}14 \cdot 4 \\
6 \cdot 0\end{array}$ & $\begin{array}{l}14.6 \\
10.0\end{array}$ & $\begin{array}{r}10.9 \\
3.4\end{array}$ \\
\hline & $77 \cdot 7$ & $69 \cdot 9$ & $52 \cdot 4$ \\
\hline & $\begin{array}{l}4.7 \\
0.8\end{array}$ & $\begin{array}{l}3.5 \\
2.0\end{array}$ & $\begin{array}{l}\text { na } \\
\text { na }\end{array}$ \\
\hline & $\begin{array}{l}0.1 \\
1.6\end{array}$ & $\begin{array}{l}1.0 \\
3.0\end{array}$ & $\begin{array}{l}\text { na } \\
0.2\end{array}$ \\
\hline & $7 \cdot 2$ & $9 \cdot 5$ & na \\
\hline
\end{tabular}

Liquid milk (pint)

Condensed milk (pint equivalent)

Total milk and cream (pint oripint equivalent)

Cheese

Carcass meat

Bacon and ham

Other meat

Total meat

Fish

Eggs (no.)

Butter

Margarine

Other fats

Total fats

Sugar

Preserves

Total sugar and preserves

Potatoes

Fresh grcen vegetables

Other vegetables

Total vegetables

Fresh fruit

Other fruit

Total fruit

Bread

Flour

Cakes and biscuits

Other cereals

Total cereals

Tea

Coffee

Cocoa

Branded food drinks

Total beverages

NFS, National Food Survey; na, not available.

dishes, vegetables, milk puddings and fruit, but during the survey week none baked cakes, although two had done so in the previous week, and only three made puddings containing flour. This suggests that a time-consuming individual dietary survey may lead to some simplification of cooking procedures. It is possible, too, that the use of 
containers for measuring such foods as sugar may cause the subject to use abnormally small amounts of the food in the container or to fail to record additions made to the container during the week of survey.

Conclusion. These inquiries did not resolve the problem of the discrepant $1000 \mathrm{kcal}$, though they did show that the reason for the conflicting findings must lie in the methods used, especially in relation to easily stored, cheap sources of energy, such as fats, sugar, flour and potatoes, rather than in the samples surveyed. The next step was to scrutinize the technique of the National Food Survey.

\section{Studies from National Food Survey records}

Before June 195I, food consumption was estimated by summing recorded purchases, quantities entering the household without payment ('free' food) and the change in larder stocks between the beginning and end of the survey week. If the amount of food bought was not exceptional during that week, addition to and withdrawals from larder stocks should cancel out over the year, given a large enough sample. In fact the housewife could, and did, save herself trouble by postponing shopping until after the survey week, and meanwhile drew on the stocks to which her attention had been directed. Accordingly, in June 195 I the weighing of larder stocks was discontinued. For the sample as a whole, the new technique improved the estimates of expenditure on food and did not worsen those of food consumption (Ministry of Food: National Food Survey Committee, I953, Appendix A); but at the time the effect of the change was not examined for separate groups of the population.

Procedure. The next step was therefore to compare the energy value of food consumption for corresponding groups during the first half of $195 \mathrm{I}$, before the change of technique, and the first half of I953 (Ministry of Agriculture, Fisheries and Food: National Food Survey Committee, 196r). For the same periods, the average consumption of individual foods by single female old-age pensioners was compared, and a similar comparison was made for all households (Ministry of Agriculture, Fisheries and Food, unpublished records).

Results. Table 5 shows that for single female old-age pensioners, the estimated energy value of food consumption rose by $500 \mathrm{kcal} / \mathrm{head}$ daily after the change in technique. The only other groups to exhibit marked increases were pensioner households as a whole and the remainder of the lowest income group, both of which contain large proportions of elderly women living alone.

When larder stocks were measured, pensioners, like others, tended to draw upon them, especially for fats, eggs, preserves, canned meats, potatoes, fruits, cakes and biscuits. For a few foods, however, they differed from the general sample in purchasing more than they consumed; these items included sugar, syrup and treacle, flour and bread (Ministry of Agriculture, Fisheries and Food, unpublished records).

Average purchases in the two periods are not strictly comparable, because of changes in available supplies and the increase in the basic pension from $26 s$. a week in the first half of $195 \mathrm{I}$ to $32 \mathrm{~s}$. $6 \mathrm{~d}$. in the corresponding months of 1953 . Nevertheless, it is remarkable that estimated consumption by pensioners in 1953 exceeded their 
measured consumption in $195 \mathrm{I}$ for all foods except butter, suet and dripping, cooked and canned meats, fish and miscellaneous items. The differences were mostly large; those for carcass meat, bacon, eggs, sugar and tea are associated with relaxations in rationing, but improved supplies do not explain the recorded increases for syrup and treacle (a threefold rise), flour (also particularly large), bread and other cereal foods, fruit, potatoes and other vegetables. There seems to be a tendency for the more detailed survey to accentuate the pensioners' well-known preference for butter rather than margarine; this is in line with the corresponding finding in the First Greater London Inquiry (Table 4).

Table 5. National Food Survey: mean daily energy value (kcal/head) of household diets of particular groups, before and after the weighing of larter stocks was discontinued

\begin{tabular}{|c|c|c|c|c|}
\hline \multicolumn{2}{|c|}{ Class } & $\begin{array}{l}195 \mathrm{I} \\
\text { Jan.-Feb. } \\
\text { and } \\
\text { Apr.-May }\end{array}$ & $\begin{array}{c}1953 \\
\text { Jan.-June }\end{array}$ & \multirow{2}{*}{$\begin{array}{c}\text { Excess } \\
1953 \text { over I95I } \\
-10\end{array}$} \\
\hline \multirow{3}{*}{\multicolumn{2}{|c|}{$\begin{array}{l}\text { All households } \\
\text { Class A } \\
\text { Class B }\end{array}$}} & 2480 & 2470 & \\
\hline & & 2500 & 2340 & -160 \\
\hline & & 2510 & 2440 & -70 \\
\hline \multicolumn{2}{|c|}{ Class C } & 2500 & 2520 & +20 \\
\hline \multicolumn{2}{|c|}{ Class D (excluding old-age pensioner households) } & 2370 & 2480 & +110 \\
\hline \multicolumn{2}{|c|}{ Old-age pensioner households } & 2190 & 2480 & +290 \\
\hline \multicolumn{2}{|c|}{ Single female old-age pensioners } & 2140 & 2640 & +500 \\
\hline \multicolumn{2}{|c|}{ Households with I man and I woman: only } & 2810 & 2830 & +20 \\
\hline & $+i$ child & $254 c^{\prime}$ & 2490 & -50 \\
\hline & +2 children & 23901 & 2260 & -130 \\
\hline & +3 children & $223^{\circ}$ & 2130 & -100 \\
\hline & $\begin{array}{l}+4 \text { or more } \\
\text { children }\end{array}$ & 2150 & 2090 & -60 \\
\hline & + adolescents & 2710 & 2770 & +60 \\
\hline & $\begin{array}{l}\text { + children and } \\
\text { adolescents }\end{array}$ & $245^{\circ}$ & 2420 & -30 \\
\hline \multicolumn{5}{|c|}{ Gross weekly income of head o: household } \\
\hline Class & I 951 & \multicolumn{2}{|c|}{1953} & \\
\hline $\begin{array}{l}\text { A } \\
\text { B } \\
\text { C } \\
\text { D }\end{array}$ & $\begin{array}{l}£ 13 \text { or more } \\
£ 8 \text { but under } £, 13 \\
£ 4 \text {. } 1 \text { os. but under } £ 8 \\
\text { Under } £ 4 . \text { ros. }\end{array}$ & \multicolumn{2}{|c|}{$\begin{array}{l}£ 15 \text { or more } \\
£ 9 \text { but under } £_{15} \\
£ 6 \text { but under } £ 9 \\
\text { Uncler } £_{6}\end{array}$} & \\
\hline
\end{tabular}

Conclusion. The earlier technique caused understatement of purchases, as opposed to consumption, in all types of household; the later technique corrected this but seems to have induced single elderly women to depart from their usual buying habits during the survey week.

\section{Second Greater London Inquiry}

The next step was to test the hypothesis, that a survey that places the emphasis on purchases rather than actual use will cause single elderly women to increase their purchases of certain storable foods.

There are three ways in which a change of habits may bias the results of a survey: the household may diminish or increase its larder stocks; eating habits may change; 
or more or less food may be wasted, when the household is under observation. Any or all of these changes may occur, to an extent depending on the method used.

It was decided to do a food budgetary survey with recording of larder stocks, with special precautions to eliminate end-effects. Ideally, the interviewer should arrive before breakfast on the Ist day of the survey and make the final inspection at bedtime on the 7 th day. In practice, the log-book used when larder stocks were weighed contained records for 8 days and the instruction was to time the two weighings to fall between the same two meals.

Procedure. In this experiment, made in October 1959 by the Social Survey Division of the Central Office of Information, special record books containing pages for 9 days were used. The housewife was asked to continue the record until the interviewer returned to collect the book and measure larder stocks, usually on the 8th day. The ninth page might be necessary if the first call occurred late on the rst day; the final stock check might then have to be deferred until the 9 th. In practice it has been found impossible to carry out two larder inspections exactly 7 days apart, but corrections were made for the end-effects by allowing for any purchases made and food consumed between the required end-points and the actual larder inspections, i.e. between the beginning of the Ist day and the first larder inspection sometime on that day, and between bedtime on the 7 th day and the final larder inspection, usually on the 8th day. To assist in making these end-corrections, the times of all shopping expeditions and of the two weighings were noted, and the interviewer was instructed to draw a line across the record book below any purchases made before her arrival on the Ist day, so that they would not be included in the estimated 7 days' consumption. Some additional details of ingredients and quantities were obtained, by questioning, for meals involved in either of the end-corrections.

The recording of larder stocks was limited to the foods for which the largest discrepancies had been found in the previous experiments, namely, margarine, cooking fats, sugar, flour and potatoes, together with butter, to cover all fats, and eggs, because they were easy to measure. The interviewers were particularly careful about the purchases and use of these foods, without drawing the housewife's attention too obviously to them.

For each food, except potatoes and eggs, the description and weight in ounces of each separate packet or container of food, whether opened or unopened, were recorded at the first inspection, and again at the last. Containers (e.g. bowls) had often been replenished from the packets. The weight of all potatoes in stock and the number of eggs were also recorded. The presence of any home-made cakes, biscuits or pastry was noted, since it provided evidence of the use of flour and fats.

After the final larder stock check, the interviewer asked questions on shopping habits, in general, and, in particular, on buying habits and use of sugar, flour and fats. She also recorded, if possible, how much sugar the informant was observed to take in her tea.

As elderly women aged 60-69 surveyed in Greater London between July 1957 and June $195^{8}$ had already been revisited, the sample consisted of women aged $5^{8-67}$ when interviewed between July $195^{6}$ and June 1957 and those aged 60-69 when inter- 
viewed between July 1958 and March 1959 . The fifty-nine women in these categories provided twenty-three usable records; the remainder are accounted for as follows:

$\begin{array}{lllr}\text { Dead } & 2 & \text { Refused to participate } & 12 \\ \text { No longer living alone } & 4 & \text { Interviewer fell ill } & 3 \\ \text { Not traced } & 7 & \text { Record book considered unreliable } & 4 \\ \text { Not contacted } & 4 & \text { Total } & 36\end{array}$

Results. In this study, apart from the ist day which was usually fully recorded by the interviewer, $41 \%$ of the items were recorded solely by the informant, $50 \%$ were recorded by the informant but elaborated by the interviewer after questioning and $9 \%$ were recorded by the interviewer-these were purchases remembered when the meals were being entered or discussed, or revealed when the interviewer probed for likely purchases. Even so, items may have been omitted, or perhaps entered twice. This procedure was an elaboration of that used at the intermediate and final interviews in the National Food Survey.

Estimates of consumption of the seven foods under consideration are given in Table 6, with estimates from previous inquiries. Line $(a)$ is based solely on the purchases recorded as having been made in the first 7 days of record-keeping. Line (b) gives the extent to which stocks of the foods in the larder ran down between the two inspections. Line $(c)$ is the sum of $(a)$ and $(b)$ and thus estimates consumption as the pre-195I National Food Survey did. In line $(d)$ this estimate is adjusted to allow for the fact that the first inspection was not made at the beginning of the Ist day or the second at the end of the $7^{\text {th, so that }}(b)$ covers a somewhat different period from $(a)$. Line $(e)$ gives estimates for sugar and flour based on the informant's view on how long her normal purchase was thought to last. Line $(f)$ gives the purchases recorded by the same women for the National Food Survey up to 3 years previously (one woman whose purchases then contributed $\mathrm{I}_{4} 4 \mathrm{Oz}$. to the average sugar purchases shown for line $(f)$ had since been put on a sugar-free diet).

Line $(g)$ is based on National Food Survey records for January-March $195^{8}$ of fifty elderly women living alone.

Line $(h)$ gives the purchases recorded by the first ten women surveyed in Paisley during 7 days (J. V. G. A. Durnin, E. C. Blake, J. M. Brockway \& E. A. Drury, unpublished results). In line $(j)$ these figures are adjusted for the diminution of larder stocks and for the unusually high proportion of meals taken away from home.

Lines $(k)$ and $(l)$ relate to the eight elderly women who took part in the First Greater London Inquiry. Line $(k)$ gives 'as purchased" weights derived from the individual dietary survey in January 1959 , line $(l)$ the purchases which the same women recorded in the normal National Food Survey during July 1957-June 1958 .

Standard errors are given whenever possible; they emphasize the fact that the sample could with advantage have been larger, but even so the differences are very striking. The right-hand column gives the total energy value of the seven foods in $\mathrm{kcal} /$ day. All the National Food Survey records give kcal equivalents between 1023 and I $107((f),(g)$ and $(l))$. A similar approach with recording of larder stocks gives about $760 \mathrm{kcal}(d)$; the net effect of the adjustments for changes in larder stocks and endcorrections is small $((a),(c)$ and $(d))$. Finally, the individual dietary surveys show much 


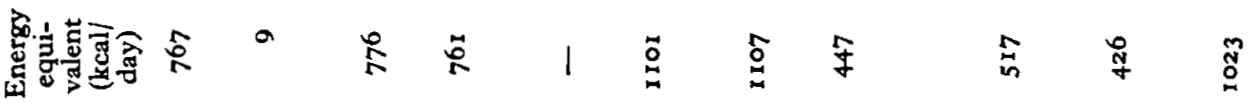

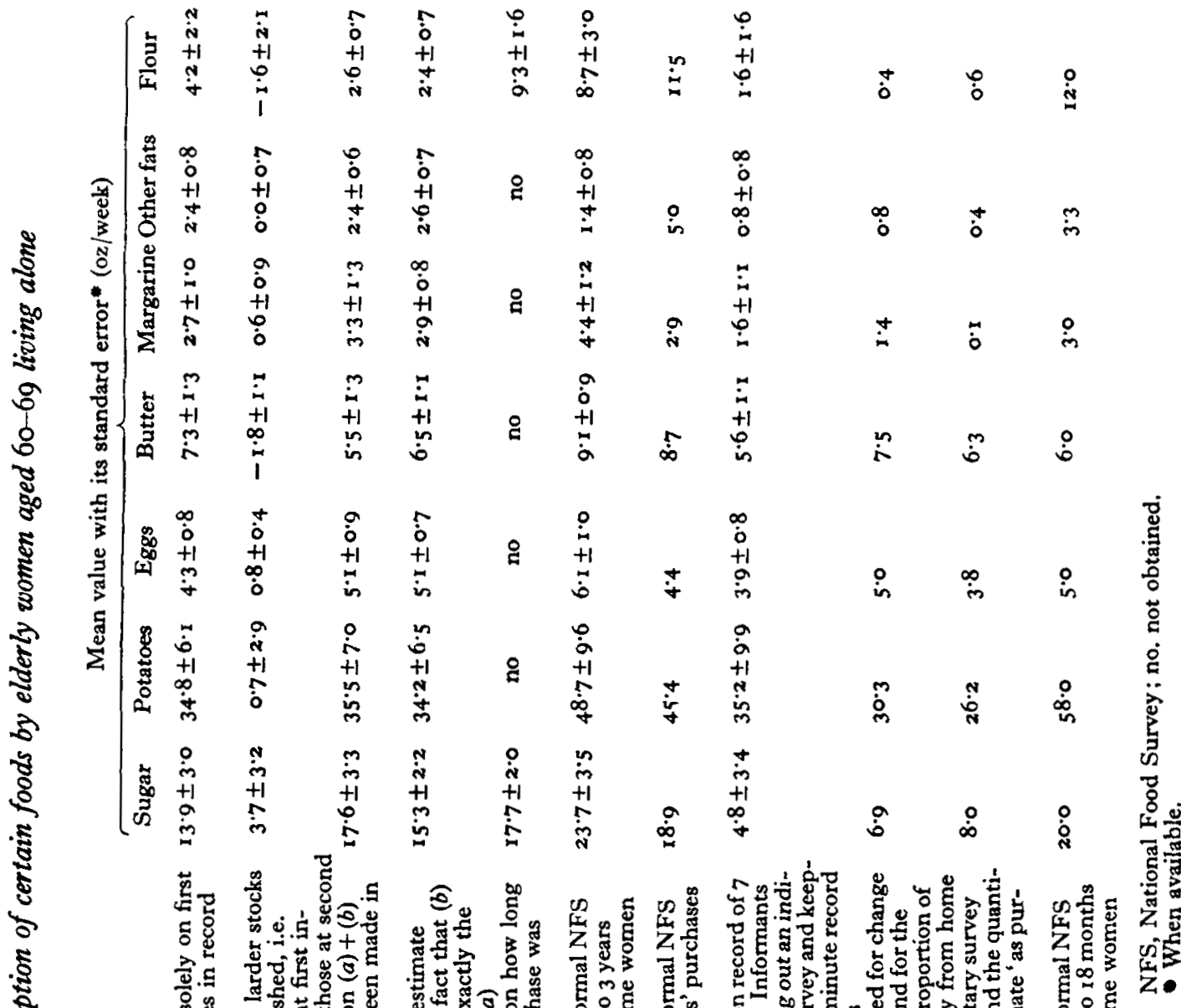

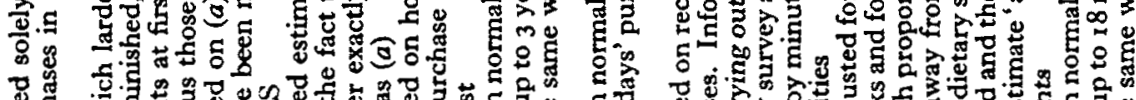

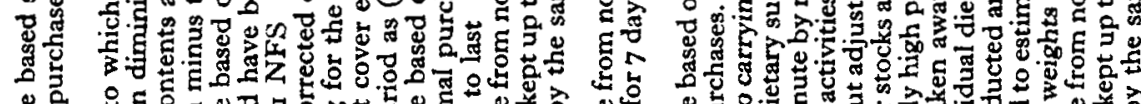

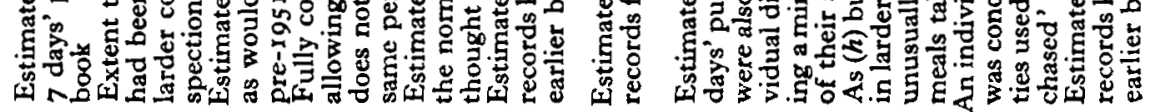

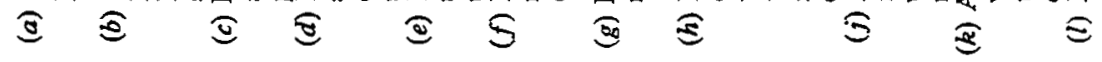
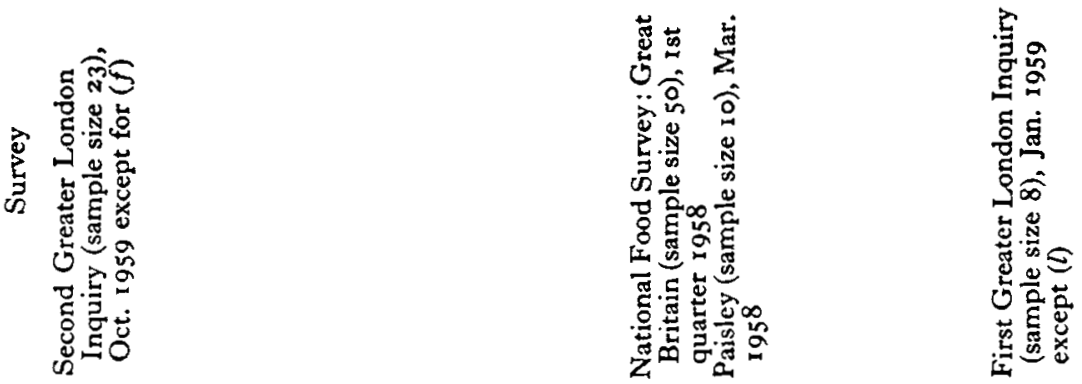
lower kcal equivalents of about $400-500((h),(j)$ and $(k))$. The largest differences between $(d)$ and $(j)$ or $(k)$ occur for sugar, flour, margarine and other fats, and these will be discussed separately.

Use of sugar. Of the twenty-three women in the present inquiry, twenty said that they normally bought sugar in $2 \mathrm{lb}$ packets, two in $\mathrm{r} \mathrm{lb}$ packets and one said that she bought a $2 \mathrm{lb}$ and $\mathrm{I} / \mathrm{lb}$ packet in alternate weeks. Sirce the normal purchase was $32 \mathrm{oz}$, it is not surprising that the standard errors for estimates $(a)$ and $(c)$ are about $50 \%$ greater than that for the fully corrected estimate $(d)$. The non-correspondence of the period between larder inspections and the 7 days' purchases produced an apparent consumption of $60 \mathrm{oz}$ for one woman.

The average $(a)$ of $13.9 \mathrm{oz}$ purchased is much less than the purchases $(f)$ of $23.7 \mathrm{oz}$ recorded previously in the National Food Survey by the same women. The fully corrected estimate $(d)$ of 15.3 oz lies between them, and is fairly close to the estimate (e) of $17.7 \mathrm{oz}$ based on how long the women thought their normal purchase lasted. It seems reasonably certain that the weekly consumption of sugar by such subjects as these is of the order of $\mathrm{Ilb} /$ head, not $\frac{1}{2} \mathrm{lb}$ as found in the individual dietary surveys $(j)$ and $(k)$.

The state of the larder at the first inspection helps to explain this difference. Of the twenty-three women, thirteen had enough sugar to last for 2 weeks or more, six for over I week and only four had less than a week's supply; with their attention drawn to these stocks, some of the other nineteen might well defer purchasing further sugar. The individual dietary surveys in which sugar was measured into a container also drew the housewife's attention to her stocks. Only two of the ten Paisley women bought any sugar (one $2 \mathrm{lb}$, one $\mathrm{x} \mathrm{lb}$ ); the rest were consuming their stocks, and it is difficult to be sure that stock changes are fully recorded. In the study now described, only seven of the twenty-three women kept all their ordinary sugar (excluding icing and preserving sugar) in one lot. Six had two lots, ten had three or more; of these, one had four, two had seven and another eleven. In the pre-195I National Food Survey the measurement of stocks was probably simpler, because of sugar rationing.

At the final interview the informants were asked about the hot drinks they had taken the previous day. They consumed an average of $36 \frac{1}{2}$ teaspoonfuls of sugar a week in this way, equivalent to $7-9$ oz, or about half their total. Eight of the twenty-three women also used sugar on cereals. Other appreciable uses were with fruit dishes and milk puddings; only two baked cakes.

Use of flour. Of the twenty-three women, eight said they normally bought their flour in $3 \mathrm{lb}$ packets, thirteen in $\mathrm{I} \mathrm{lb}$ packets, and two said they normally did not buy flour. The average (e) of $9 \cdot 3 \mathrm{oz}$ based on the time they thought a packet usually lasted does not agree with the fully corrected estimate $(d)$ of $2: 4$ oz but is compatible with the average $(f)$ of $8.7 \mathrm{oz}$ which the same subjects recorded in the National Food Survey. In the two individual dietary surveys only 0.4 and $0.6 \mathrm{oz}(k)$ were recorded; this finding suggests that cooking procedures are simplified during such surveys.

Only two of the twenty-three larders contained home-made cakes and scones at the first inspection. Five women baked cakes, scones or pastry during the week, and the larders of three of these contained home-baked goods at the final inspection. There 
is thus no indication that the survey had prevented home-baking, and the figures seem consistent with the estimate $(d)$ of $2.4 \mathrm{oz}$. If this is accepted, the much higher National Food Survey figures must be explained by stocking-up, and even in the experiment described now, larder stocks increased slightly. The estimate based on habit of $9.3 \mathrm{oz}$ would have to be discounted as representing past rather than present habits; it carries less weight than for sugar, since sugar is used much more regularly than flour.

Use of margarine and cooking fats. Margarine and cooking fats are associated with baking, but the latter fats are used particularly for frying. Four of the twenty-three women said they never fried, but seventeen said they used cooking fat, lard or dripping for frying and one also used margarine. There is ample evidence of fried foods in the menus. Five women used margarine instead of butter on bread and toast, and one used butter and margarine mixed together. The evidence of this inquiry suggests that use of margarine and cooking fats in the two individual dietary studies was unrealistically low.

Conclusions. Even from this small sample, it appears that the National Food Survey as at present conducted causes elderly women living alone to record too great a consumption of certain storable foods of relatively high energy value, particularly flour and sugar. Most of the discrepancy probably arises from a build-up of stocks during the survey week, rather than overstatement of actual purchases or a change in eating habits. In contrast, individual dietary surveys appear to underestimate consumption of sugar, flour and margarine and cooking fats.

\section{Further examination of National Food Survey records}

It thus appears to be well established that if larder stocks are not recorded at the first interview, elderly women living alone tend to make abnormal purchases of certain foods, a conclusion which provides at least part of the explanation sought unsuccessfully by Durnin $\&$ Blake (rg6z). The next step was to examine whether this disturbance of their normal buying behaviour operated uniformly over the period of the survey or whether it could be associated with any particular days of the survey week.

The purchases of sugar recorded by 214 female old-age pensioners living alone surveyed by the National Food Survey during the second and third quarters of 1960 are given in Table 7. Entries in bold-face type relate to the day on which the survey began. No records were begun on Sunday during the period, and only four on Saturday; the latter have not been included in the analysis. No purchases took place on Sunday.

To establish the normal pattern of purchases, the rows of Table 7 were combined so as to give equal weight to the five 'cohorts' beginning on Monday, Tuesday, Wednesday, Thursday and Friday. The resulting estimates of the percentages of pensioners making a purchase on each weekday are given in the final row of the table.

Thus the survey indicates that in a representative week $25.5 \%$ of pensioners would not buy any sugar but would draw on their larder stocks. This percentage is remarkably uniform for the five cohorts beginning on each weekday. (For the whole 
Table 7. Purchases of sugar recorded by female perzioners living alone, April-September 1960

\begin{tabular}{|c|c|c|c|c|c|c|c|c|}
\hline \multirow{2}{*}{$\begin{array}{l}\text { Day survey } \\
\text { commenced }\end{array}$} & \multirow{2}{*}{$\begin{array}{l}\text { No. of } \\
\text { persons }\end{array}$} & \multicolumn{6}{|c|}{ Percentage of persons making purchases on } & \multirow[b]{2}{*}{ Total } \\
\hline & & Mon. & Tues. & Wed. & Thurs. & Fri. & Sat. & \\
\hline Monday & 57 & $7 \cdot 0$ & $14 \%$ & $3 \cdot 5$ & $12 \cdot 3$ & $2 I \cdot I$ & 14.0 & $71 \cdot 9$ \\
\hline Tuesda & $4 \mathrm{I}$ & $7 \cdot 3$ & 49 & $12 \cdot 2$ & 22 & $12 \cdot 2$ & 19.5 & $78 \cdot 0$ \\
\hline Wednesday & 37 & $2 \cdot 7$ & $2 \cdot 7$ & 8.r & $18 \cdot 9$ & $24 \cdot 3$ & 16.2 & $73 \cdot 0$ \\
\hline 'Thursday & $4 \mathrm{I}$ & $7 \cdot 3$ & $9 \cdot 8$ & 4.9 & I7. I & $26 \cdot 8$ & $7 \cdot 3$ & $73 \cdot 2$ \\
\hline Friday & 38 & $\circ$ & 13.2 & $5 \cdot 3$ & $7 \cdot 9$ & $34 \cdot 2$ & 15.8 & $76 \cdot 3$ \\
\hline \multirow{2}{*}{\multicolumn{2}{|c|}{$\begin{array}{l}\text { Unweighted mean } \\
\text { percentages }\end{array}$}} & $4 \cdot 9$ & $8 \cdot 9$ & $6 \cdot 8$ & $15 \cdot 6$ & 23.7 & $14 \cdot 6$ & 74.5 \\
\hline & & \multicolumn{6}{|c|}{ Average quantity purchased (oz per head) } & \\
\hline $\begin{array}{l}\text { Day survey } \\
\text { commenced }\end{array}$ & $\begin{array}{l}\text { No. of } \\
\text { persons }\end{array}$ & Mon. & Tues. & Wed. & Thurs. & Fri. & Sat. & Total \\
\hline Monday & 57 & $x \cdot 96$ & 3.93 & 0.84 & $3 \cdot 37$ & 4.77 & $3 \cdot 65$ & $18 \cdot 52$ \\
\hline Tuesday & $4 I$ & $2 \cdot 34$ & & & & & 5.85 & $23 \cdot 79$ \\
\hline Wednesday & 37 & 0.86 & 0.86 & 3.03 & $5 \cdot 19$ & $6 \cdot 49$ & $4 \cdot 76$ & $2 \pi \cdot 19$ \\
\hline Thursday & $4 \mathrm{I}$ & $2 \cdot 73$ & $2 \cdot 34$ & & 6.63 & $5 \cdot 85$ & $1 \cdot 56$ & $20 \cdot 28$ \\
\hline Friday & 38 & 0 & 2.95 & $\mathrm{I} \cdot 68$ & $2 \cdot 11$ & 8.84 & $2 \cdot 95$ & $18 \cdot 53$ \\
\hline
\end{tabular}

Entries in bold face type relate to the day on which the survey began.

Table 8. Sugar purchases by female pensioners living alone, April-September 1960: Ist and 2nd days of survey week compared with 3 rd-6th days

\begin{tabular}{lccccc} 
& $\begin{array}{c}\text { Observed no. of } \\
\text { persons purchasing }\end{array}$ & \multicolumn{2}{c}{$\begin{array}{c}\text { Expected no of persons } \\
\text { purchasing }\end{array}$} & \\
$\begin{array}{l}\text { Day survey } \\
\text { commenced }\end{array}$ & $\begin{array}{c}\text { Ist and 2nd } \\
\text { days }\end{array}$ & $\begin{array}{c}3 \text { rd-6th } \\
\text { days }\end{array}$ & $\begin{array}{c}\text { Ist and 2nd } \\
\text { days }\end{array}$ & $\begin{array}{c}\text { 3rd-6th } \\
\text { days }\end{array}$ & Total \\
Monday & 12 & 29 & 7.6 & 33.4 & 41 \\
Tuesday & 7 & 25 & 6.7 & 25.3 & 32 \\
Wednesday & 10 & 17 & 8.1 & 18.9 & 27 \\
Thursday & 18 & 12 & 15.8 & 14.2 & 30 \\
Friday & 19 & 10 & 14.9 & 14.1 & 29 \\
Total & 66 & 93 & 53.2 & 105.8 & 159
\end{tabular}

National Food Survey sample, the proportion of households buying sugar during the week of the survey was $84.4 \%$ in the second and third quarters of r960.)

If the inception of the survey did not disturb the normal pattern of purchases, or disturbed it in a manner which operated uniformly throughout the week, the pattern found above would be reproduced in each of the five sohorts, subject of course to random deviations. In fact the difference between the theoretical and observed frequencies appear to be systematic, as Table 8 shows. In all five cohorts, more purchases of sugar were made on the first and second shopping days of the survey week than would have been expected on those days of the week; the differences do not individually attain statistical significance, but if the 5 starting days are taken together the excess of purchases in the first 2 shopping days is significant $(P<0.05)$ and the results for the five cohorts are compatible.

The increased frequency of purchases of sugar on the first 2 shopping days is not accompanied by any increase in the average size of individual purchases, which was $27.39 \mathrm{oz}$ for those 2 days compared with $27.35 \mathrm{oz}$ for the remaining 4 . The average 
quantity bought on the first 2 days was $8.45 \mathrm{oz}$ a head and on the last $4,11.89 \mathrm{oz}$, making $20.34 \mathrm{oz}$ in all. Assuming 6 purchasing days a week, if the rate of purchase in the first $\mathbf{2}$ days was maintained throughout the week the total weekly purchases would amount to $25.35 \mathrm{oz} /$ head. If the last 4 days are regarded as typical, the estimate for a normal week would be $17.84 \mathrm{oz}$ instead of $20.34 \mathrm{oz}$, a result much more nearly in line with the other evidence, and especially with informants' estimates of how long they think a lb of sugar lasts them.

Inspection of the findings suggests that the excess is greater on the ist day than on the 2nd; and this is the more striking since the log-book may have been placed at any time on the ist shopping day, and the later the initial interview, the shorter the period of time in which it could affect buying behaviour on that day.

\section{General conclusion}

This series of studies leads to the conclusion that elderly women living alone buy an excess of certain storable foods when participating in the National Food Survey as conducted since 1951 , and that for sugar, at least, the abnormally heavy buying is concentrated in the first 2 days of the survey. Their behaviour is probably different if their attention is drawn to their larder stocks, because they then realize that they have a considerable reserve in store. If this conclusion is true, then the fact that in their experiment Durnin \& Blake ( 1962 ) measured changes in larder stocks even though they did not use them in all their calculations explains their inability to parallel the National Food Survey finding of abnormally high calorie consumption by elderly women living alone. In particular, it illuminates the uniquely low assessment of calorie intake by the allegedly current National Food Survey method in the comparison of different methods shown in their Table 2: the fact that attention was drawn to larder stocks probably meant that purchases were reduced (as in the pre-1951 National Food Survey) and were supplemented from larder stocks, so that because these were not taken into account in their calculation a lower estimate of intake was made.

On the other hand, the technique of individual dietary survey may lead to some underestimate of calorie consumption, possibly because of the use of containers for certain foods in frequent use. The close agreement between calorie intake and calorie expenditure in the Paisley survey does not necessarily invalidate this conclusion. There are unavoidable limitations on the accuracy with which either intake or expenditure of energy can be assessed, and the numbers surveyed were small in relation to the differences commonly encountered between measurement of intake and measurement of requirement in individuals during one week. In any event, the hypothesis is untested, perhaps untestable, that behaviour is relevantly altered by the experiment itself. Keeping a record of one's activities may change these activities. We do not think the possibility can be excluded that the individual dietary surveys underestimated normal calorie consumption by perhaps $100-150 \mathrm{kcal} /$ day, and that the energy requirement of these women was about $2000 \mathrm{kcal} /$ day.

If so, about $900 \mathrm{kcal}$ remain to be accounted for. The estimates of wastage obtained in the Paisley study and the First Greater London Inquiry were extremely low: 65 and $36 \mathrm{kcal} /$ day respectively. Presumably when there is no survey more is wasted. 
A figure of waste of $10 \%$ is usually accepted: in this instance, some $200 \mathrm{kcal}$. A higher figure is by no means excluded. The build-up in larder stocks of the storable foods to which the study reported on p. 420 was limited could account for some 340 kcal daily. This would leave no more than 360 of the discrepant $1000 \mathrm{kcal}$ still to be accounted tor. These non-perishable foods supply less than half the energy intake, and it could well be that overpurchase of other foods occurs to some extent during the survey week. It might be inferred from the difference between the $500 \mathrm{kcal}$ jump between I95 I and 1953 (Table 5) and the $340 \mathrm{kcal}$ attributed to stocking-up of certain storable foods that overpurchase of the remaining foods is not likely to have been less than $160 \mathrm{kcal}$. The balance left unexplained is thus no more than $200 \mathrm{kcal}$. It must be emphasized that the errors involved in this sequence of calculations all affect this final residual, and in view of the degree of approximation involved a close reconciliation was not to be expected.

Only I $\%$ of the persons taking part in the National Food Survey are elderly women living alone, and their overpurchase of storable and peshaps of other foods when under observation does not appear to extend to other types of household (Ministry of Agriculture, Fisheries and Food: National Food Survey Committee, r96r).

\section{SUM MARY}

I. Food consumption of elderly women living alone, as assessed by the National Food Survey as at present operated, is about $1000 \mathrm{kcal} / \mathrm{h}$ ead daily greater than that assessed by individual dietary survey. A series of studies was made to investigate the cause of the difference.

2. In 1957,39 I female old-age pensioners who lived alone provided National Food Survey records. The energy value of their consumption was about $2660 \mathrm{kcal} / \mathrm{head}$ daily. In 1958,335 such women provided records. Their food consumption ranged in energy value from $2900 \mathrm{kcal} / \mathrm{head}$ daily for the $60-64$ age-group to about $2300 \mathrm{kcal} /$ head daily at 80 and over.

3. The diets of eight women aged 60-69 who lived alone in Greater London and who participated in the National Food Survey about a year previously were investigated by individual survey in January 1959. The mean value of their daily intake was $1862 \mathrm{kcal} / \mathrm{head}$. Preparation and plate wastage was measured during the last 3 days of the survey and amounted daily to $36 \mathrm{kcal} / \mathrm{head}$.

4. Much greater consumption of certain storable foods, fats, sugar, flour and potatoes, was recorded by the eight women in the National Food Survey than in the individual dietary survey. Their National Food Survey pattern of consumption was very similar to that recorded by all elderly women aged 60-69 living alone in the National Food Survey for the first quarter of $195^{8}$.

5. Before June I95I changes in larder stocks of foods were measured as part of the routine of the National Food Survey. This was not done after that date. For the whole National Food Survey sample, the value of food obtained for consumption appeared to be unaffected by the change, but for single old-age pensioners it rose by $500 \mathrm{kcal} /$ head between the first half of 195 I and the first half of 1953 . 'Consumption' in 1953 
exceeded that in 1951 in most foods. It was concluded that the present National Food Survey technique causes such women to depart from their usual buying habits during the survey week.

6. In October I959 a food budgetary survey was made on twenty-three elderly women aged 60-69 living alone in Greater London who had previously participated in the National Food Survey. Larder stock changes were measured for fats, sugar, flour, potatoes and eggs. The results of this survey were compared with those of individual dietary surveys and it was concluded that the National Food Survey as at present conducted causes elderly women living alone to record too great a consumption of certain storable foods, particularly flour and sugar. In contrast, individual dietary surveys appear to underestimate consumption of sugar, flour, margarine and cooking fats.

7. The purchases of sugar recorded by 214 female old-age pensioners living alone and surveyed by the National Food Survey in the second and third quarters of ig6o were examined according to the day of the week on which they were made. Significantly more purchases were made on the ist and 2nd shopping days of the survey week than would have been expected.

8. Of the discrepant $1000 \mathrm{kcal}$, individual dietary surveys on such women may underestimate consumption by $100-150 \mathrm{kcal} /$ day; wastage may account for more than that recorded, possibly $200 \mathrm{kcal} /$ day; the build-up in larder stocks of storable foods can account for $340 \mathrm{kcal} /$ day; overpurchase of other foods is not likely to be less than $160 \mathrm{kcal} / \mathrm{day}$. The energy value left formally unexplained is thus no more than 200 $\mathrm{kcal} / \mathrm{day}$. This is a balancing item, affected by the approximation necessarily involved in each step of the calculation, and no exact reconciliation was to be expected.

9. Only I $\%$ of all persons taking part in the National Food Survey are elderly women living alone, and their anomalous buying behaviour when under observation does not appear to occur in other groups when surveyed.

\section{REFERENCES}

Baines, A. H. J. \& Hollingsworth, D. F. (1955). Proc. Nutr. Soc. 14, 77.

Durnin, J. V. G. A. \& Blake, E. C. (1962). Brit. F. Nutr. 16, 26 r.

Durnin, J. V. G. A., Blake, E. C. \& Brockway, J. M. (1957). Brit. Y. Nutr. 1 ז, 85.

Durnin, J. V. G. A., Blake, E. C., Brockway, J. M. \& Drury, E. A. (1961). Brit. Y. Nutr. $15,499$.

FAO (1957). F.A.O. nutr. Stud. no. I 5 .

Garry, R. C., Passmore, R., Warnock, G. M. \& Durnin, J. V. G. A. (1955). Spec. Rep. Ser. med. Res. Coun., Lond., no. 289.

Harries, J. M. \& Hollingsworth, D. F. (1953). Brit. med. J. i, 75.

Kemsley, W. F. F. (1953). Ann. Eugen., Lond., 18, 22.

Ministry of Agriculture, Fisheries and Food: National Food Survey Committee (1956). Studies in Urban Household Diets 1944-49. London: H.M. Stationery Office.

Ministry of Agriculture, Fisheries and Food: National Food Survey Committee (1961). Domestic Food Consumption and Expenditure, 1959. London: H.M. Stationery Office.

Ministry of Food: National Food Survey Committee (1953). Domestic Food Consumption and Expenditure, 1951. London: H.M. Stationery Office. 